\title{
Diferenciação de micobactérias por PCR multiplex
}

\author{
Differentiation of micobacteria by multiplex PCR
}

\author{
Diogo da Rocha Poroca ${ }^{1}$, Andrea Santos Lima ${ }^{1}$, Juliana Falcão de Araújo Lima ${ }^{1}$, \\ Heidi Lacerda Alves da Cruz ${ }^{1}$, Rosana de Albuquerque Montenegro ${ }^{1}$, \\ Fábio Lopes de Melo ${ }^{2}$, Haiana Charifker Schindler ${ }^{1}$ e Lílian Maria Lapa Montenegro ${ }^{1}$
}

\begin{abstract}
RESUMO
0 trabalho visou à otimização de um método baseado na reação em cadeia da polimerase multiplex - para diferenciação de micobactérias de interesse para a saúde pública. A PCR Multiplex baseou-se na amplificação simultânea do gene bsp65, presente em todo gênero Mycobacterium, do gene dnaJ, presente apenas em Mycobacterium tuberculosis e Mycobacterium avium e da sequência de inserção IS6110 presente no complexo Mycobacterium tuberculosis, gerando amplicons de $165 \mathrm{pb}, 365 \mathrm{pb}$ e $541 \mathrm{pb}$, respectivamente. 0 limite de detecção foi de 1 fg para 0 alvo hsp65, 100pg para o dnaJ e 0,1fg para o IS6110. A PCR multiplex detectou até 100pg de DNA de Mycobacterium tuberculosis. 0 sistema demonstrou ser específico e sensível na detecção de Mycobacterium tuberculosis, Mycobacterium bovis, Mycobacterium avium e Mycobacterium smegmatis. Os resultados obtidos utilizando cepas de referência demonstraram que a PCR multiplex pode ser uma ferramenta rápida, sensível e específica na diferenciação de micobactérias.
\end{abstract}

Palavras-chaves: Micobactérias. PCR multiplex. IS6110. dnaJ. hsp65.

\begin{abstract}
This study aimed to optimize a method based on the polymerase chain reaction - multiplex PCR - for differentiation of mycobacteria species of interest for public health. The multiplex PCR was based on simultaneous amplification of the $h s p 65$ gene, which is present in all species of the Mycobacterium genus, the dnaJ gene, which is present only in Mycobacterium tuberculosis and Mycobacterium avium and the IS6110 insertion sequence, which is present in the Mycobacterium tuberculosis complex, generating amplicons of $165 \mathrm{bp}, 365 \mathrm{bp}$ and $541 \mathrm{bp}$, respectively. The detection limit was 1 fg for the hsp65 target, $100 \mathrm{pg}$ for dnaJ and 0.1 fg for IS6110. The multiplex PCR detected down to $100 \mathrm{pg}$ of DNA of Mycobacterium tuberculosis. The system was shown to be specific and sensitive for detection of Mycobacterium tuberculosis, Mycobacterium bovis, Mycobacterium avium and Mycobacterium smegmatis. The results obtained using reference strains of mycobacteria showed that multiplex PCR may be a fast, sensitive and specific tool for differentiation of mycobacteria.
\end{abstract}

Key-words: Mycobacteria. Multiplex PCR. IS6110. dnaJ. hsp65.

Identificado por Robert Koch, em 1882, o Mycobacterium tuberculosis é a principal espécie do gênero Mycobacterium que compõe um grupo formado pelas espécies: Mycobacterium tuberculosis, Mycobacterium. africanum, Mycobacterium. bovis, Mycobacterium bovis-BCG, Mycobacterium microti, Mycobacterium caprae e Mycobacterium pinnipetti, denominado complexo Mycobacterium tuberculosis ${ }^{14}$. Além das espécies causadoras de tuberculose, existem ainda as micobactérias não causadoras de tuberculose (MNT). Atualmente, a expressão micobactérias não causadoras de tuberculose é a mais comumente utilizada para referir-se as espécies do gênero

1. Laboratório de Imunoepidemiologia, Departamento de Imunologia, Centro de Pesquisas Aggeu Magalhães, Fundação Oswaldo Cruz, Recife, PE. 2. Laboratório de Doenças Transmissíveis, Departamento de Parasitologia, Centro de Pesquisas Aggeu Magalhães, Fundação Oswaldo Cruz, Recife, PE.

Apoio financeiro: CPqAM/FIOCRUZ e FACEPE

Endereço para correspondência: Dra. Lílian Maria Lapa Montenegro. Campus da UFPE. Av. Moraes Rego s/n, Caixa Postal 7472, 50670-420 Recife, PE.

Tel: 5581 2101-2681; Fax: 5581 3453-2449

e-mail: lilian@cpqam.fiocruz.br

Recebido para publicação em 25/06/2009

Aceito em 09/11/2009
Mycobacterium, com exceção de Mycobacterium tuberculosis e Mycobacterium leprae, que podem ser patogênicas para o ser humano, causando as enfermidades conhecidas como micobacterioses. As micobactérias não causadoras de tuberculose estão amplamente distribuídas no meio ambiente, tendo sido isoladas na água, incluindo água canalizada, solo, animais e inclusive em instrumentos cirúrgicos, por falha no processo de esterilização e soluções desinfectates ${ }^{5}$. Como ainda não foi demonstrado que as micobactérias não tuberculosas são transmitidas pessoa a pessoa, com o isolamento destes microrganismos em amostras de pele, aparato respiratório ou tubo digestivo de indivíduos sadios, se supõe que a colonização ou infecção por estes microorganismos tem origem ambiental ${ }^{10}$. A infecção ocorre por inalação, inoculação ou ingestão de material contaminado por micobactérias, sendo excepcional a transmissão entre humanos ${ }^{47}$.

Enquanto as características patogênicas clássicas de Mycobacterium tuberculosis têm sido mais extensivamente descritas, pouco se sabe sobre as MNT. Os primeiros quadros clínicos produzidos pelas MNT foram descritos na década de 50 e por muitos anos foram considerados ocasionais e quase 
sempre ligados a situações de imunodeficiência. Nos últimos 20 anos, tem se tornado uma infecção relativamente mais frequente, relacionada ou não com quadros de imunodepressã $0^{10}$. Os grupos que tem o risco aumentado em desenvolver doenças causadas por micobactérias não causadoras de tuberculose incluem: fibrose cística, enfisema, bronquectasia, doenças obstrutivas pulmonares crônicas, neumoconiosis, silicoses e portadores de imunodeficiência ${ }^{7}$. No entanto, as MNT são reconhecidas, também, como importantes patógenos em indivíduos imunocompetentes ${ }^{15}$.

Estudos revelam que doenças atribuídas as MNT estão aumentando no Brasil, iniciado pela pandemia HIV/AIDS e associado ao crescente número de surtos decorrentes de cirurgias e procedimentos estéticos com equipamentos esterilizados incorretamente. Em razão da gravidade desse fato, o Ministério da Saúde classificou essas infecções como doença de notificação compulsória ${ }^{20}$. Porém, a notificação não está sendo feita de rotina em todos os estados brasileiros, incluindo Pernambuco onde não se tem dados notificados de casos de infecção por micobactérias não causadoras de tuberculose.

0 diagnóstico de tuberculose apresenta inúmeras dificuldades: as imagens radiológicas pulmonares nem sempre são conclusivas, a baciloscopia possui sensibilidade limitada, a cultura apesar de ser considerada padrão ouro, necessita de 6 a 8 semanas para a visualização das colônias, prolongando o diagnóstico definitivo. A sensibilidade do diagnóstico convencional está comprometida em pacientes paucibacilares, sendo frequente o resultado negativo $^{1227}$. Um diagnóstico final tardio do paciente pode, dessa forma, resultar em aumento da taxa de mortalidade. Visto que o estabelecimento do regime terapêutico depende da espécie de micobactéria, a identificação apropriada do organismo pode ser crítica para a adoção de uma terapia adequada ${ }^{29}$.

Nas infecções causadas por MNT, para se definir o diagnóstico é necessário avaliar os achados clínicos e radiológicos do paciente e como os mesmos podem não diferir clinicamente da tuberculose, é de fundamental importância para o estabelecimento do diagnóstico a correlação clínico-laboratorial ${ }^{2}$. A baciloscopia é o exame que se baseia na pesquisa de bacilos álcool-ácido resistentes, sendo indicado nos casos onde ocorre suspeita de micobacterioses, porém apresenta a desvantagem de não diferenciar morfologicamente as espécies de micobactérias, sendo assim necessária a realização da cultura e identificação da espécie que pode ser feita por métodos fenotípicos, moleculares ou pela combinação de ambos. A identificação das micobactérias é realizada a partir de culturas puras e as espécies geneticamente distintas podem apresentar resultados fenotípicos similares ou idênticos. No Brasil, a técnica de PRA- $h s p 65$, tem possibilitado a identificação rápida de diversas espécies de micobactérias ${ }^{20}$. 0 diagnóstico diferencial entre a tuberculose e as doenças causadas pelas micobactérias não tuberculosas (MNT) é de grande importância, pois apresentam fundamental diferença em sua epidemiologia, prognóstico e tratamento.

A pesquisa de novos métodos laboratoriais que possibilitem o diagnóstico mais rápido e preciso torna-se um objetivo importante a ser alcançado ${ }^{9}$. Vários testes de diagnóstico para a tuberculose utilizando a reação em cadeia da polimerase (PCR) têm sido descritos e propostos, tanto métodos in house como métodos comerciais ${ }^{17}$. A PCR é um método considerado sensível e específico que vem sendo utilizado na detecção de DNA ou RNA de micobactérias, diretamente de espécimes clínicos como escarro, lavado brônquico, líquido cefalorraquidiano, líquido ascítico, material de biópsia, entre outros ${ }^{113132}$. A sensibilidade da técnica de PCR está relacionada, principalmente, ao número de cópias da sequência alvo presente no genoma do patógeno, o tipo de iniciadores, bem como inibidores presentes na amostra clínica. A PCR multiplex é uma técnica que possibilita a detecção de várias sequiências de DNA alvo em uma única reação, apresentando vantagens como rapidez, especificidade e reprodutibilidade na detecção, contribuindo na identificação de focos primários de infecção por micobactérias de forma mais rápida 3 .

As sequências alvo exploradas até o momento demonstraram níveis variáveis de sensibilidade bem como dificuldade de reprodutibilidade quando utilizadas isoladamente. Os marcadores moleculares mais comumentemente utilizados são o $16 \mathrm{~S}$ rDNA e o elemento de inserção IS6110 ${ }^{18}{ }^{30} .0$ IS6110 está presente apenas nas espécies do complexo Mycobacterium tuberculosis, sendo usado para diferenciá-lo das $\mathrm{MNT}^{13}$. 0 gene dnaJ codifica uma proteína de estresse e é altamente conservado entre as bactérias. Os membros da família Mycobacteriacea possuem o dna j e esta sequiência nesses organismos provou ser útil na identificação a nível de espécies ${ }^{21} 26$. Outro gene de interesse que vem sendo estudado por diferentes grupos de pesquisa é o gene hsp65, comum a todas as bactérias do gênero Mycobacterium que codifica o antígeno de $65 \mathrm{kDa}$ e bastante utilizado para diferenciação de espécies de $\mathrm{MNT}^{24}$. 0 presente trabalho teve como objetivo à padronização de um método baseado em PCR multiplex, capaz de identificar e diferenciar a espécie Mycobacterium tuberculosis de outras cepas do complexo Mycobacterium tuberculosis, o Mycobacterium bovis e das micobactérias não tuberculosas de interesse para a saúde publica, utilizando a amplificação de diferentes sequências moleculares (IS6110, dnaJ, hsp65) numa única reação.

\section{MATERIAL E MÉTODOS}

Padronização das técnicas de reação em cadeia da polimerase. Para realização dos experimentos de padronização da técnica foi utilizado DNA genômico extraído e purificado de cepa de referência de Mycobacterium tuberculosis (H37Rv), Mycobacterium bovis, Mycobacterium avium, Mycobacterium smegmatis e Mycobacterium fortuitum, obtido de cultura em meio Löwenstein Jensen. As cepas foram cedidas pelo laboratório de micobactérias da Universidade Federal do Rio de Janeiro (UFRJ).

Extração e purificação de DNA de micobactérias. Foi utilizado o kit comercial Genomic PrepTM - Cells and Tissue DNA Isolation Kit (Amersham Biosciences) seguindo instruções do fabricante, porém com algumas modificações: a) aquecimento prévio da amostra a $90^{\circ} \mathrm{C}$ por 10 minutos em solução de lise do próprio kit; b) adição de $3 \mu \mathrm{L}$ de proteinase $\mathrm{K}(20 \mathrm{mg} / \mathrm{ml})$ e incubação a $55^{\circ} \mathrm{C}$ por no mínimo $6 \mathrm{~h}$; c) após 
a adição de $3 \mu \mathrm{L}$ da RNAse, foi adicionada a amostra, álcool isopropílico (1:1) e armazenada a $-20^{\circ} \mathrm{C}$, por no mínimo $3 \mathrm{~h}$, para posterior centrifugação. A quantificação do DNA foi realizada espectrofometricamente (Ultraspec 3000, Pharmacia Biotech). 0 DNA foi estocado a $-20{ }^{\circ} \mathrm{C}$ até sua utilização.

Padronização das condições da técnica de reação em cadeia da polimerase. Para avaliação das condições de amplificação dos alvos moleculares IS6110, dnaJ e hsp65, foram realizadas três reações simples de amplificação, nas seguintes condições: I) A mistura de reação foi composta de tampão da Taq DNA polimerase $1 \mathrm{X}$ (Invitrogen), $2.5 \mathrm{mM} \mathrm{MgCl}_{2}$ (Invitrogen) 2mM de dNTP (Invitrogen), 20 pmol de cada iniciador P1 e P2 (Invitrogen) e 2.5U de Taq DNA polimerase (Invitrogen), com volume final de $50 \mu \mathrm{l}$. A fase de desnaturação foi realizada a $94^{\circ} \mathrm{C}$ por 20 segundos, anelamento a $63^{\circ} \mathrm{C}$ por 20 segundos e extensão $72^{\circ} \mathrm{C}$ por 1 minuto, em um total de 32 ciclos, com uma etapa de extensão final de $72^{\circ} \mathrm{C}$ por 10 minutos $^{3}$. Os iniciadores P1: 5' CTA GGT CGG GAC GGT GAG GCC AGG 3' e P2: 5' CAT TGC GAA GTG ATT CCT CCG GAT 3') amplificam um fragmento de $165 \mathrm{pb}$ do gene que codifica o antígeno 65KDa de Mycobacterium tuberculosis. II) A mistura de reação foi composta de tampão da Taq DNA polimerase 1X (Invitrogen), 2.5 $\mathrm{mM} \mathrm{MgCl}_{2}$ (Invitrogen), 50pmol de cada iniciador P3 e P4 (Invitrogen), 2mM de dNTP (Invitrogen) e 2.5U de Taq DNA polimerase (Invitrogen), com volume final de $50 \mu \mathrm{l}$. A fase de desnaturação foi realizada a $94^{\circ} \mathrm{C}$ por 30 segundos, anelamento $65^{\circ} \mathrm{C}$ por 1 minuto e extensão $72^{\circ} \mathrm{C}$ por 2 minutos, em um total de 38 ciclos, com uma etapa de extensão final de $72^{\circ} \mathrm{C}$ por 10 minutos $^{3}$. Os iniciadores P3: 5' AAG AGG AAG GAG AGA GGG G 3' e P4: 5' GTC GTT GAG GTT GAA CTC 3' amplificam um fragmento de $365 \mathrm{pb}$ do gene $d n a \mathrm{~J}$, presente em Mycobacterium tuberculosis e Mycobacterium avium e ausente em outras espécies de micobactérias. III) A mistura de reação foi composta de tampão da Taq DNA polimerase 1X (Invitrogen), 2,5 $\mathrm{mM} \mathrm{MgCl}_{2}$ (Invitrogen), 10pmol de cada iniciador P5 e P6 (INVITROGEN), 2mM de dNTP (Invitrogen) e 2.5U de Taq DNA polimerase (Invitrogen), com volume final de $50 \mu \mathrm{l}$. A fase de desnaturação foi realizada a $94^{\circ} \mathrm{C}$ por 1,5 minuto, anelamento $65^{\circ} \mathrm{C}$ por 2 minutos e extensão $72^{\circ} \mathrm{C}$ por 3 minutos, em um total de 40 ciclos, com uma etapa de extensão final de $72^{\circ} \mathrm{C}$ por 10 minutos ${ }^{3}$. Os iniciadores P5: 5' GTG CGG ATG GTC GCA GAT AT 3' e P6: 5' CTC GAT GCC CTC ACG GTT CA 3') amplificam o fragmento de 541pb do elemento de inserção IS6110, presente apenas nas cepas do complexo Mycobacterium tuberculosis.

Avaliação da temperatura de anelamento dos iniciadores na PCR multiplex. Foi avaliada através da realização de um gradiente de temperatura de anelamento, variando de $54^{\circ} \mathrm{C}$ a $57,8^{\circ} \mathrm{C}\left(54^{\circ} \mathrm{C}, 54,8^{\circ} \mathrm{C}, 55,7^{\circ} \mathrm{C}, 56,5^{\circ} \mathrm{C}\right.$, $57,2^{\circ} \mathrm{C}, 57,8^{\circ} \mathrm{C}$ ) utilizando o termociclador Mastercycle Gradient (Eppendorf AG). A reação foi desenvolvida nas mesmas condições da PCR multiplex.

Padronização das condições da técnica de PCR multiplex. A reação em cadeia da polimerase multiplex foi realizada utilizando os três pares de iniciadores em uma única reação, para a amplificação dos fragmentos alvos descritos nas reações de PCR (I), (II) e (III). A reação foi composta de tampão da Taq DNA polimerase 1X (Invitrogen), 2,5mM de $\mathrm{MgCl}_{2}$ (Invitrogen), 2mM de dNTP (Invitrogen), 2.5U de Taq DNA polimerase (Invitrogen) e 20pmol, 50pmol e 10pmol dos iniciadores P1 eP2, P3 e P4, P5 e P6, respectivamente. Em cada mistura de reação, foram adicionados $5 \mu \mathrm{l}$ de 1 ng de DNA genômico purificado de cada cepa de referência de micobactéria, perfazendo um volume final de $50 \mu \mathrm{l}$. Os ciclos de amplificação constaram de uma etapa de pré-incubação de $85^{\circ} \mathrm{C}$ por 5 minutos, desnaturação inicial de $94^{\circ} \mathrm{C}$ por 10 minutos, desnaturação a $94^{\circ} \mathrm{C}$ por 1 minuto, anelamento a $57,2^{\circ} \mathrm{C}$ por 1 minuto e extensão a $72^{\circ} \mathrm{C}$ por 2 minutos, composta por 40 ciclos, com uma etapa de extensão final a $72^{\circ} \mathrm{C}$ por 10 minutos $^{3}$. Todas as reações de amplificação foram realizadas no termociclador Mastercycle Gradient (Eppendorf AG) e utilizados controles negativos, livre de DNA.

Detecção dos fragmentos amplificados por PCR. Dez $\mu l$ dos produtos de PCR foram analisados através de eletroforese em gel de agarose a 2,0\% corado com brometo de etídio. Os fragmentos de DNA separados através de eletroforese foram visualizados em um transluminador de luz ultravioleta e fotografados com um sistema de documentação Kodak (Gel Logic 100 Imaging System), utilizando o software Kodak molecular imaging software 4.0.0. 0 marcador de peso molecular utilizado foi o Low DNA Mass Ladder (Invitrogen).

Avaliação da especificidade e limiar de detecção das técnicas de PCR. A especificidade foi avaliada utilizando quantidades conhecidas (100pg) de DNA genômico purificado de cepa de referência de micobactérias (Mycobacterium tuberculosis (H37Rv), Mycobacterium bovis, Mycobacterium avium, Mycobacterium smegmatis, Mycobacterium fortuitum) e DNA genômico humano. 0 limite de detecção foi definido utilizando concentrações conhecidas de DNA genômico purificado de Mycobacterium tuberculosis (H37Rv) e diluídas serialmente, em água ultra pura tipo I, em fator 10 (1ng a 0,01fg). Nessa fase, foi dada atenção particular as condições de ciclagem principalmente temperatura de anelamento, concentrações de $\mathrm{Mg}^{++}$e de iniciadores, visando minimizar o aparecimento de bandas inespecíficas e maximizar o limiar de detecção dos fragmentos específicos.

Análise da PCR multiplex utilizando amostra clínica. A PCR multiplex foi avaliada utilizando amostra de sangue total coletada de paciente com diagnóstico confirmado de tuberculose extrapulmonar através de critérios clínicos, epidemiológicos e laboratoriais, realizado pelo médico do serviço de saúde de Pernambuco. A amostra de sangue foi submetida à extração e purificação de DNA segundo o protocolo de Rossetti, 1997 para posterior utilização no sistema de PCR multiplex.

\section{RESULTADOS}

0 teste de especificidade revelou uma amplificação específica do DNA de Mycobacterium tuberculosis (faixas 1, 2 e 3) não havendo amplificação com DNA humano (faixa 4). Os fragmentos de $165 \mathrm{pb}, 365 \mathrm{pb}$ e $541 \mathrm{pb}$ foram amplificados, respectivamente, pelos iniciadores P1 e P2, P3 e P4, P5 e P6 (Figura 1).

0 limite de detecção nas técnicas de PCR simples utilizando DNA genômico de cepa de referência de Mycobacterium tuberculosis 
com os iniciadores P1 e P2, P3 e P4, P5 e P6 foi de 1fg, 100pg e $0,1 \mathrm{fg}$, respectivamente. Na PCR multiplex, a quantidade mínima de DNA detectado na eletroforese de gel de agarose foi 100pg.

A temperatura de anelamento ideal na amplificação específica dos fragmentos alvo através da PCR multiplex foi padronizada para $57,2^{\circ} \mathrm{C}$, pela observação da presença dos fragmentos específicos (165pb, 365pb e 541pb) e pela ausência de formação de amplicons inespecíficos. A concentração do íon magnésio na qual foram visualizados os três fragmentos alvo (165pb, 365pb e $541 \mathrm{pb})$ com maior nitidez foi a de $2,5 \mathrm{mM}$, sendo estabelecida como concentração padrão nos experimentos da PCR multiplex.

Na PCR multiplex, para o Mycobacterium tuberculosis, os três fragmentos foram amplificados $(165 \mathrm{pb}, 365 \mathrm{pb}$ e 541pb). Para o Mycobacterium bovis, foram amplificados os fragmentos de $165 \mathrm{pb}$ e 541pb. Em Mycobacterium smegmatis e Mycobacterium fortuitum, foi observado um amplicon menor que o fragmento de $165 \mathrm{pb}$ (cerca de 20-40pb), presente em Mycobacterium bovis ou Mycobacterium tuberculosis. Não houve amplificação do fragmento de $365 \mathrm{pb}$ em Mycobacterium bovis, Mycobacterium smegmatis e Mycobacterium fortuitum. Foram amplificados os fragmentos de $365 \mathrm{pb}$ e o menor que $165 \mathrm{pb}$ (cerca de 20-40pb) na cepa de Mycobacterium avium, não sendo observada a amplificação do fragmento de $541 \mathrm{pb}$. A amostra de sangue testada revelou amplificação específica dos três fragmentos (165pb, 365pb e $541 \mathrm{pb})$, indicando o perfil para Mycobacterium tuberculosis (Figura 2).

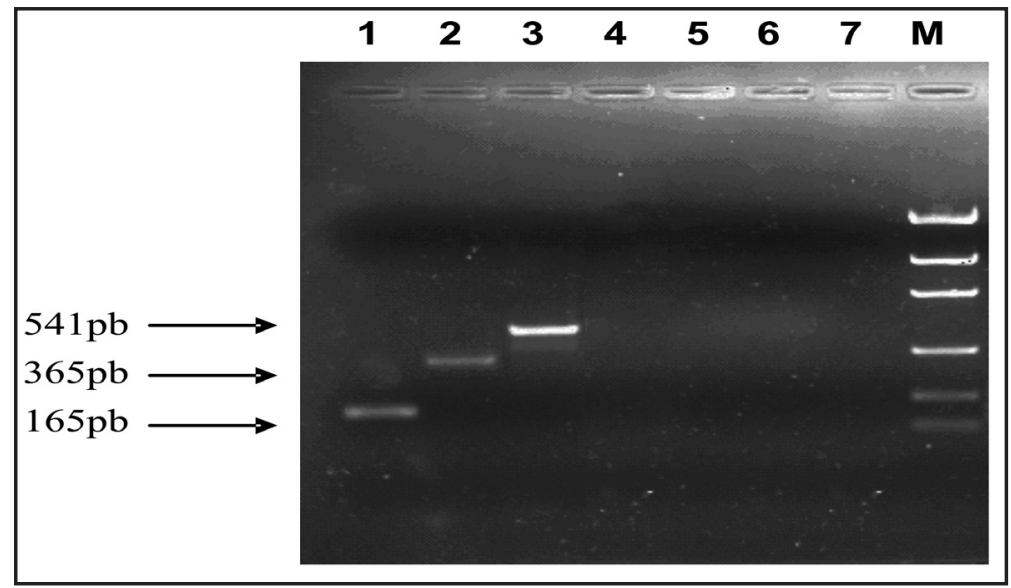

\section{FIGURA 1}

Eletroforese em gel de agarose demonstrando os amplicon de $165 \mathrm{pb}, 365 \mathrm{pb}$ e $541 \mathrm{pb}$. Faixas 1,2 e 3 referem-se à amplificação com os iniciadores P1 e P2; P3 e P4; P5 e P6 com 100pg DNA genômico de cepa de referência Mycobacterium tuberculosis (H37Rv). As faixa 4, 5 e 6, referem-se a amplificação de 5ng de DNA genômico humano com os iniciadores P1 e P2; P3 e P 4; P5 e P6. Faixa 7, controle negativo livre de DNA; M, Marcador de peso molecular (Low DNA Mass Ladder).

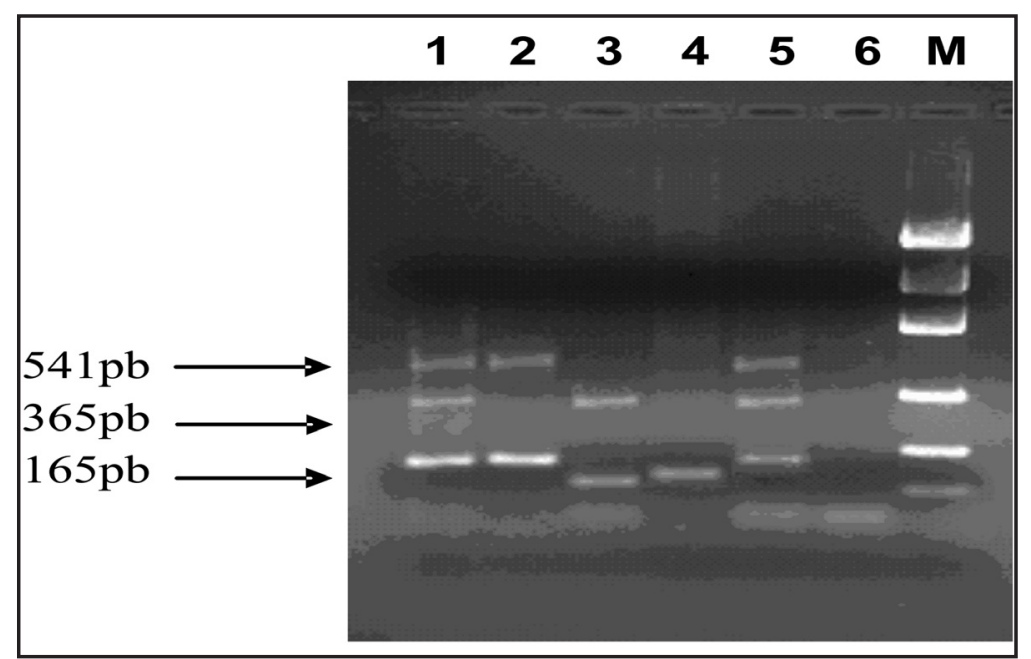

FIGURA 2

Eletroforese em gel de agarose demonstrando a padronização da PCR multiplex com diferentes cepas de referência de micobactérias e com amostra de sangue de paciente com tuberculose extrapulmonar. Faixa 1, Mycobacterium tuberculosis (H37Rv); Faixa 2, Mycobacterium bovis; Faixa 3, Mycobacterium avium; Faixa 4, Mycobacterium smegmatis; Faixa 5, Mycobacterium tuberculosis (proveniente de sangue de paciente); Faixa 6, controle negativo; M, Marcador (Low DNA Mass Ladder). 


\section{DISCUSSÃo}

Muitos ensaios baseados em PCR têm sido desenvolvidos para o diagnóstico da tuberculose. Embora esses ensaios tenham se mostrado úteis, possuem algumas limitações. Quando oligonucleotídeos são usados para amplificar uma sequência gênero-específica, geralmente necessita-se de sondas individuais que hibridizam com os amplicons gerados para a diferenciação entre as espécies. Na amplificação de uma região específica do complexo Mycobacterium tuberculosis, as espécies que formam o complexo não podem ser diferenciadas. Finalmente, quando oligonucleotídeos são usados para amplificar sequências específicas de Mycobacterium tuberculosis, as espécies de Mycobacterium bovis e Mycobacterium africanum não podem ser detectadas, sendo também essas espécies causadoras de TB em humanos ${ }^{6}$.

A PCR multiplex é um método proposto para uma detecção rápida e diferenciação de espécies de micobactérias, sendo considerado sensível e específico em relação aos métodos convencionais ${ }^{3}$. Os pares de oligonucleotídeos utilizados neste trabalho demonstraram ser específicos para cada sequência alvo. Pao e cols ${ }^{26}$ testaram os oligonucleotídeos usados no presente trabalho para o gene $b s p 65$ com DNA genômico extraído e purificado de cepas de referência de Mycobacterium tuberculosis, Mycobacterium bovis BCG (Bacillus CalmetteGuérin) e em outras nove espécies de MNT (Mycobacterium. avium, Mycobacterium chelonae, Mycobacterium fortuitum, Mycobacterium gordonae, Mycobacterium kansasii, Mycobacterium paratuberculosis, Mycobacterium phelei, Mycobacterium smegmatis, Mycobacterium xenopi) e obtiveram os mesmos resultados descritos neste trabalho com a obtenção de um amplicon de $165 \mathrm{pb}$ para as Mycobacterium tuberculosis e Mycobacterium bovis e amplicons com aproximadamente $20 \mathrm{a}$ $40 \mathrm{pb}$ menor que o fragmento de $165 \mathrm{pb}$, para as MNT. Testaram também os oligonucleotídeos com 18 espécies de bactérias Gram positivas e Gram negativas, algumas delas comumente encontradas no trato respiratório e não observaram formação de nenhum amplicon, comprovando a especificidade dos oligonucleotídeos para o DNA de micobactérias. 0 limite de detecção de DNA de Mycobacterium tuberculosis obtido em seus experimentos foi de 0,1pg (100fg). Em contrapartida, o limite de detecção encontrado no presente estudo foi de $1 \mathrm{fg}(0,001 \mathrm{pg})$. 0 resultado obtido demonstra uma alta sensibilidade deste sistema na detecção de DNA de Mycobacterium tuberculosis. 0 sistema usando oligonucleotídeos específicos para 0 alvo $b s p 65$ demonstrou ser específico para DNA de micobactérias não ocorrendo amplificação quando utilizado com DNA genômico humano.

Estudos anteriores propuseram a amplificação da sequiência de inserção IS1245 para identificação do Mycobacterium avium. Ferreira e cols ${ }^{8}$ demonstraram que a detecção de Mycobacterium avium por amplificação do IS1245, mostrou-se negativa em amostras já identificadas como Mycobacterium avium por testes bioquímicos. Oliveira e $\operatorname{cols}^{25}$ descreveram variabilidades genéticas em cepas de Mycobacterium avium em estudos com pacientes aidéticos relatando a ausência do alvo em três isolados.
Estes estudos demonstram a instabilidade da sequência IS1245 na identificação de Mycobacterium avium, abrindo espaço para o uso de outros marcadores, visando uma identificação mais confiável deste microrganismo.

Os oligonucleotídeos usados por Takewaki e $\operatorname{cols}^{28}$ são gênero específicos e baseados na sequência do gene $d n a$ J de Mycobacterium tuberculosis dirigidos para a amplificação da região entre as posições 1377-1741 de Mycobacterium tuberculosis. Em estudo com 19 espécies diferentes de micobactérias o amplicon, de 365pb foi apenas observado em Mycobacterium tuberculosis e Mycobacterium avium não sendo observado em nenhuma outra espécie de micobactéria. Ainda em seu estudo, relataram que a amplificação do fragmento de $365 \mathrm{pb}$ é mais intensa em Mycobacterium tuberculosis do que em Mycobacterium avium. 0 gene dnas é mais útil do que o gene codificante de rRNAs como alvo para o desenvolvimento de oligonucleotídeos espécie-específicos, pois a sequiência de nucleotídeos do dnaj é altamente variável entre as espécies de MNT. Estes resultados foram levados em consideração na escolha deste alvo para o nosso estudo.

No presente estudo, o limite de detecção do sistema utilizando oligonucleotídeos para o alvo dnaJ foi de 100pg de DNA de Mycobacterium tuberculosis. 0 sistema utilizando oligonucleotídeos específicos para o dnaJ também não demonstrou amplificação de DNA humano, somente amplificando DNA de micobactérias, mais especificamente de Mycobacterium tuberculosis e Mycobacterium avium.

Weil e cols $\mathrm{s}^{31}$ demonstraram que uma PCR multiplex tendo como alvo a sequência de inserção IS6110 pode ser usada para caracterização do complexo Mycobacterium tuberculosis em relação às MNT. A principal vantagem do alvo IS6110 é que está frequentemente presente em várias cópias dentro do genoma do Mycobacterium tuberculosis, em média de 6 a 20 cópias ${ }^{19}$. Este número de cópias aumenta o limite de deteç̧ão da técnica, o qual é especialmente importante em infecções paucibacilares.

Estudos demonstraram que a técnica de PCR tendo como base o alvo IS6110, não foi muito específica para o Mycobacterium tuberculosis e também apresentaram resultados positivos para DNA de cepas de MNT tais como Mycobacterium scrofulaceum, Mycobacterium kansasii e Mycobacterium fortuitum. Yuen e $\operatorname{cols}^{32}$ demonstraram a existência de cepas de Mycobacterium tuberculosis que pareciam possuir apenas uma ou nenhuma cópia do IS6110. A maioria dessas cepas foi isolada de pacientes de origem asiática. Devido a isso, o uso do IS6110 como alvo único para PCR pode, em alguns casos, levar a resultados falso-negativos. Técnicas de PCR baseadas exclusivamente na sequência IS6110 não discriminam entre o Mycobacterium tuberculosis e outras micobactérias do complexo ${ }^{3}$. 0 IS6110 é o alvo mais utilizado em ensaios baseados em PCR para diagnóstico de TB. Como muitos estudos ainda usam essa sequência para identificação do complexo Mycobacterium tuberculosis e nenhum estudo relatou cepa de Mycobacterium tuberculosis com ausência do elemento de inserção IS6110 no Brasil, este alvo foi um dos escolhidos para a nossa proposta de diagnóstico complementar. 
Em estudos realizados por Kox e cols ${ }^{18}$, com os oligonucleotídeos P5 e P6 visando à amplificação do alvo IS6110, o limite de detecção alcançado em seus experimentos variou entre $10 \mathrm{fg}$ e $1 \mathrm{fg}$ dependendo da cepa de referência utilizada no experimento. No presente estudo, obtivemos uma melhor sensibilidade, sendo detectado 0,1fg de DNA, o equivalente ao DNA de menos de uma micobactéria (5fg), utilizando DNA de cepa de referência de Mycobacterium tuberculosis (H37Rv). Também foi encontrada uma alta sensibilidade na detecção de DNA de Mycobacterium tuberculosis com a utilização desse sistema. A PCR utilizando os oligonucleotídeos P5 e P6 amplificou apenas DNA de micobactérias não havendo amplificação com DNA humano. Segundo Battacharya e cols ${ }^{3}$, o limite de detecção da PCR multiplex utilizando os mesmos conjuntos de oligonucleotídeos foi de 100fg, em comparação ao valor de $100 \mathrm{pg}$ obtido neste trabalho.

No presente estudo, foram observados dois fragmentos na PCR multiplex utilizando DNA de Mycobacterium bovis, o primeiro correspondente a amplificação do hsp65 (165pb) e o segundo que corresponde à amplificação da sequência de inserção IS6110 (541pb). Diferentemente do apresentado por Battacharya e cols ${ }^{3}$ que observou apenas o fragmento $165 \mathrm{pb}$, quando utilizou o DNA de Mycobacterium bovis. Como membro do complexo Mycobacterium tuberculosis, a amplificação do fragmento correspondente à sequência IS6110 em Mycobacterium bovis deveria ser observada como ocorreu no nosso trabalho.

Diferente do trabalho de Battacharya e cols ${ }^{3}$, que utilizou a temperatura de $55^{\circ} \mathrm{C}$ para a hibridização de seus oligonucleotídeos, a temperatura de $57,2^{\circ} \mathrm{C}$ demonstrou ter melhor desempenho no anelamento específico dos oligonucleotídeos, simultaneamente. Foram também realizados ensaios com a PCR multiplex utilizando diferentes concentrações de cloreto de magnésio. A concentração de 2,5mM demonstrou melhor desempenho, discordando dos achados de Battacharya e $\operatorname{cols}^{3}$ que utilizou $1,5 \mathrm{mM}$.

No experimento realizado para avaliar o desempenho da PCR multiplex, em amostra de sangue coletada de paciente com TB extrapulmonar, a técnica mostrou-se eficaz, conseguindo amplificar os três alvos moleculares, confirmando o diagnóstico de tuberculose. Negi e cols ${ }^{23}$ compararam a eficiência de vários alvos moleculares na detecção de TB por PCR e verificou as melhores sensibilidades nos alvos IS6110 e hsp65, respectivamente. Esses resultados reforçam os bons limites de detecção encontrados nas reações simples, utilizando os mesmos alvos moleculares demonstrados no presente trabalho.

Os resultados apresentados no presente estudo corroboram para uma avaliação da acurácia do sistema de PCR multiplex em vários espécimes clínicos isolados de pacientes com tuberculose pulmonar e extrapulmonar, para propor sua implementação em laboratórios de referência de micobacterioses. Neste sentido, acreditamos que tal abordagem, com alta sensibilidade e especificidade para espécies correspondentes ao complexo Mycobacterium tuberculosis e às MNT possa ser empregado como modelo auxiliar no diagnóstico da tuberculose e das micobacterioses.

\section{AGRADECIMENTOS}

À Drª Leila Fonseca do Laboratório de micobactérias da Universidade Federal do Rio de Janeiro (UFRJ) pelo fornecimento das cepas de micobactérias necessárias ao desenvolvimento deste trabalho.

\section{REFERÊNCIAS}

1. American Thoracic Society; Centers for Disease Control and Prevention; Council of the Infectious Disease Society of America. Diagnostic standards and classification of tuberculosis in adults and children. American Journal of Respiratory Critical Care Medicine 38:1376-1395, 2000.

2. American Thoracic Society Documents, An Official ATS/IDSA statement: diagnosis, treatment and prevention of nontuberculous Mycobacterial diseases. American Journal of Respiratory and Critical Care Medicine 175:367-416, 2007.

3. Bhattacharya A, Karak K, Ghosal AG, Roy A, Das S, Dandapat P, Khetaway D, Mondal DK, Bhattacharya S, Chakrabarti S. Development of a new sensitive and efficient multiplex polymerase chain reaction (PCR) for identification and differentiation of different mycobacterial species. Tropical Medicine and Internetional Health 8: 150-157, 2003.

4. Brown-Elliott BA, Wallace Jr RJ. Ifections caused by nontuberculous mycobacteria. In: Mandell Douglas, and Bennett's: Principles and Practice of Infectious disease. Volume 2, $6^{\text {th }}$ edition. Philadelphia, PA: Elsevier, p.2909-2916, 2005.

5. De Groote MA, Huitt $\mathrm{G}$. Infections due to rapidly growing mycobacteria. Clinical Infection Disease 42:1756-1763, 2006.

6. Del Portillo P, Thomas MC, Martínez E, Marañon C, Valladares B, Patarroyo ME, Lopez MC. Multiprimer PCR System for differential identification of mycobacteria in clinical simples. Journal of Clinical Microbiology 34: 324-328, 1996.

7. Esteban J, García Cía JI, Ortiz A, Fernández Roblas R. Infecciones por micobactérias atípicas. Medicine 9:3632-3638, 2006.

8. Ferreira RMC, Saad MHF, Gomes da Silva M, Fonseca LS. Non-tuberculous mycobacteria I: one year clinical isolates identification in Tertiary Hospital Aids Reference Center, Rio de Janeiro, Brazil, in pre highly active antiretroviral therapy era. Memórias do Instituto Oswaldo Cruz 97:725-729, 2002.

9. Fundação Nacional de Saúde. Controle da Tuberculose: uma proposta de integração ensino-serviço. Centro de Referência Prof. Hélio Fraga; Sociedade Brasileira de Pneumologia e Tisiologia. 5ª edição. FUNASA/CRPHF/SBPT, Ministério da Saúde, Rio de Janeiro, 2002.

10. Gómez NA. Micobacterias no tuberculosas: ¿una infeccion emergente? Anales de Pediatría 71: 185-188, 2009.

11. Gopinath K, Singh S. Urine as an adjunct specimen for the diagnosis of active pulmonary tuberculosis. International Journal of Infectious Diseases 13:374-379, 2008

12. Green C, Huggett JF, Talbot E, Mwaba P, Reither K, Zumla AI. Rapid diagnosis of tuberculosis through the detection of mycobacterial DNA in urine by nucleic acid amplification methods. Lancet Infection Disease 9:505-511, 2009

13. Hermans PWM. Insertion element IS986 from Mycobacterium tuberculosis: a useful tool for diagnosis and epidemiology of tuberculosis. Journal of Clinical Microbiology 28: 2051-2058, 1990.

14. Herrera-León L, Pozuelo-Díaz R, Moreno TM, Cobacho AV, Pilar SV, Pajares MSJ. Aplicación de métodos moleculares para la identificac0ión de las especies del complejo Mycobacterium tuberculosis. Enfermedades Infecciosas y Microbiologia Clínica, 2009. doi: 10.1016/j.eimc.2009.01.008

15. Jarzembowski JA, Young MB. Nontuberculous Mycobacterial Infections. Archives of Pathology and Laboratory Medicine 132: 1333-1341, 2008.

16. Kim H, Mun H, Kim H, Oh E, Ha Y, Bai G, Park Y, Cha C, Kook Y, Kim B. Differentiantion of mycobacterial species by $h s p 65$ duplex PCR followed by duplex-PCR-based restriction analysis and direct sequencing. Journal of Clinical Microbiology 44:3855-3862, 2006.

17. Kim MH, Yang HY, Suh JT, Lee HJ. Comparison of In-house PCR with Conventional Techniques and Cobas Amplicor M. tuberculosis ${ }^{\mathrm{TM}}$ Kit for Detection of Mycobacterium tuberculosis. Yonsei Medical Journal 49: 537-544, 2008. 
18. Kox LLF, Rhienthong D, Miranda AM, Udomsantisuk N, Ellis K, van Leeuwen J, van Heusden S, Kuijper S, Kolk AH. A more reliable PCR for detection of Mycobacterium tuberculosis in clinical samples. Journal of Clinical Microbiology 32: 672-678, 1994

19. Kurabachew M, Enger O, Sandaa R, Skuce R, Bjorvatn B. A multiplex polymerase chain reaction assay for genus-, group-, and species-specific detection of mycobacteria. Diagnostic Mycobiology and Infectious Disease 49: 99-104, 2004.

20. Ministério da Saúde. Prêmio de Incentivo em Ciência e tecnologia para o SUS: edição 20 anos de SUS 2008/Ministério da Saúde. Identificação de micobaterias pelo método de PCR - análise de restrição (PRA-hsp65) em um laboratório de referência e elaboração de um algoritmo de padrões de PRA-hsp65. Departamento de Ciência e tecnologia, Secretaria de Ciências, tecnologia e insumos estratégicos Instituto Adolfo Lutz. Editora Ministério da Saúde, p.156, 2008.

21. Morita Y, Maruyama S, Kabeya H, Nagai A, Kozawa K, Kato M, Nakajima T, Mikami T, Katsube Y, Kimura H. Genetic diversity of the dnaJ gene in the Mycobacterium avium complex. Journal of Medical Microbiology 53:813-817, 2004.

22. Nations JA, Myers JN. Nontuberculous mycobacterium in association with bronchiectasis. Disease-a-Month 54:565-572, 2008.

23. Negi SS, Anand R, Pasha ST, Gupta S, Basir SF, Khare S, Lal S. Diagnostic potential of IS6110, 38kDa, $65 \mathrm{kDa}$ and $85 \mathrm{~B}$ sequence-based polymerase chain reaction in the diagnosis of Mycobacterium tuberculosis in clinical samples. Indian Journal of Medical Microbiology 25:43-49, 2007.

24. Neonakis IK, Gitti Z, Krambovitis E, Spandidos DA. Molecular diagnostic tools in mycobacteriology. Journal of microbiological methods 75:1-11, 2008.

25. Oliveira RS, Sircili MP, Ueki SYM, Telles MAS, Schnabel B, Briones MRS, Leão SC. PCR-restriction enzyme analysis of a bone marrow isolate from human immunodeficiency virus-positive patient disclose polyclonal infection with two Mycobacterium avium strains. Journal of Clinical Microbiology 38: 4643-4645, 2000

26. Pao CC, Yen TSB, Jinn-Bang Y, Juehn-Shin M, Fiss EH, Chau-Hsiung C. Detection and Identification of Mycobacterium tuberculosis by DNA amplification. Journal of Clinical Microbiology 28:1877-1880, 1990 .

27. Restrepo BI, Gomez DI, Shipley GL, McCormick JB, Fisher-Hoch SP. Selective enrichment and detection of mycobacterial DNA in paucibacillary specimens. Journal of Microbiological Methods 67:220-229, 2006

28. Takewaki S, Okuzumi K, Ishiko H, Nakahara K, Ohkubo A, Nagai R. Genus specific polymerase chain reaction for the mycobacterial dnaJ gene and species-specific oligonucleotide probes. Journal of Clinical Microbiology 31: 446-450, 1993

29. Tanaka II, Anno IS, Leite SRA, Cooksey RC, Leite CQF. Comparison of a multiplex-PCR assay with mycolic acids analysis and conventional methods for the identification of mycobacteria. Microbiology and Immunology 47: 307-312, 2003.

30. Tortoli E. Impact of genotypic studies on mycobacterial taxonomy: the new mycobacteria of the 1990s. Clinical Microbiology Review 16: 319-354, 2003.

31. Weil A, Plikaytis BB, Butler RW, Woodley LC, Shinnick MS The mpt40 gene is not present in all strains of Mycobacterium tuberculosis. Journal of Clinical Microbiology 34:2309-2311, 1996.

32. Yuen KWL, Ross CB, Jackson MK, Dwyer B. Characterization of Mycobacterium tuberculosis strains from Vietnamese patients by southern blot hybridization. Journal of Clinical Microbiology 31: 1615-1618, 1993. 